Western University

Scholarship@Western

Biology Publications

Biology Department

Summer 8-1-2014

\title{
The overwintering biology of the acorn weevil, Curculio glandium in southwestern Ontario.
}

Hiroko Udaka

hudaka@uwo.ca

Brent J Sinclair

bsincla7@uwo.ca

Follow this and additional works at: https://ir.lib.uwo.ca/biologypub

Part of the Biology Commons

Citation of this paper:

Udaka, Hiroko and Sinclair, Brent J, "The overwintering biology of the acorn weevil, Curculio glandium in southwestern Ontario." (2014). Biology Publications. 65.

https://ir.lib.uwo.ca/biologypub/65 
1 The overwintering biology of the acorn weevil, Curculio glandium in southwestern

2 Ontario

3

4

5

6

$7 \quad$ Hiroko Udaka* and Brent J. Sinclair

8 Department of Biology, The University of Western Ontario, London, Ontario, N6A 5B7,

9 Canada.

10

$11 *$ Corresponding author.

12 Tel.: +1- 519-661-2111 x86491

13 Fax: + 1-519-661-3935

14 E-mail address: hudaka@uwo.ca

15 


\section{ABSTRACT}

The acorn weevil, Curculio glandium, is a widespread predator of acorns in eastern North America that overwinters in the soil as a larva. It is possible that low temperatures limit its northern geographic range, so we determined the cold tolerance strategy, seasonal variation in cold tolerance, and explored the physiological plasticity of overwintering larvae. Weevil larvae were collected from acorns of red and bur oak from Pelee Island, southwestern Ontario in fall 2010 and 2011. Curculio glandium larvae are freeze avoidant and larvae collected from bur oak acorns had lower supercooling points (SCPs: $-7.6 \pm 0.36{ }^{\circ} \mathrm{C}, \mathrm{LT}_{50}:-7.2^{\circ} \mathrm{C}$ ) than those collected from red oak acorns (SCPs: $-6.1 \pm 0.40{ }^{\circ} \mathrm{C}, \mathrm{LT}_{50}:-6.1{ }^{\circ} \mathrm{C}$ ). In the winter of 2010-2011, SCPs and water content decreased, however these changes did not occur in 2011-12, when winter soil temperatures fluctuated greatly in the absence of the buffering effect of snow. To examine whether larvae utilize cryoprotective dehydration, larvae from red oak acorns were exposed to $-5^{\circ} \mathrm{C}$ in the presence of ice for seven days. These conditions decreased the SCP without affecting water content, suggesting that SCP and water content are not directly coupled. Finally, long-term acclimation at $0{ }^{\circ} \mathrm{C}$ for six weeks slightly increased cold tolerance but also did not affect water content. Thus, although larval diet affects cold tolerance, there is limited plasticity after other treatments. The soil temperatures we observed were not close to lethal limits, although we speculate that soil temperatures in northerly habitats, or in years of reduced snow cover, has the potential to cause mortality in the field.

Keywords: Curculionidae, freeze avoidance, supercooling point, acclimation, cryoprotective dehydration 


\section{Introduction}

Because insects are ectotherms, and winter cold affects survival and reproduction, it is commonly predicted that warmer winters might lead to poleward expansion of temperate insects (Danks, 1991; Denlinger and Lee, 2010; Semel and Andersen, 1988). Insect cold tolerance is generally divided into freeze avoidance (insects that are killed by freezing) and freeze tolerance (insects that can withstand internal ice formation) (Denlinger and Lee, 2010). Because freeze-avoidant species cannot survive when ice forms in their bodies, their supercooling points (SCP, the temperature at which freezing occurs) equates to their lower lethal temperature (LLT). Freeze avoiding insects often seasonally depress the SCP to ensure they remain unfrozen. For example the SCP of prepupae of the emerald ash borer, Agrilus planipennis, is about $-20{ }^{\circ} \mathrm{C}$ in October and decreases to $-30{ }^{\circ} \mathrm{C}$ from December to February (Crosthwaite et al., 2011). The SCP can be decreased by various physiological means, including dehydration and accumulation of colligative cryoprotectants, such as glycerol (Chown and Nicolson, 2004). By contrast, freeze-tolerant species can survive the freezing of their body fluids, although most of them do not tolerate intracellular ice formation (Sinclair and Renault, 2010). The SCPs of freeze-tolerant insects are higher than their LLTs and SCP does not usually decrease substantially in winter. Nevertheless, many cryoprotectant mechanisms may be shared between freeze tolerance and avoidance, including polyols and antifreeze proteins (Denlinger and Lee, 2010).

The temperature conditions in overwintering microhabitats affect both the survival and fitness of insects. In some species, warm winter temperatures decrease fitness by increasing consumption of energy reserves (e.g., Irwin and Lee, 2002; 
Marshall and Sinclair, 2012; Williams et al., 2012). By contrast, other species are killed by low winter temperatures (e.g., Roland and Matter, 2013). Soil is a common overwintering site for temperate insects (Danks, 1991) and buffers the extremes of overwinter temperatures, especially in the presence of snow cover (Marshall and Sinclair, 2012) . The high moisture content of soil has facilitated the development of a cryoprotective dehydration strategy to enhance cold tolerance in permeable invertebrates overwintering in the soil (Holmstrup et al., 2002). In frozen soil, these organisms lose water to the lower energy-state ice, dehydrating them and increasing the concentration of their body fluids such that they remain unfreezeable (Pedersen and Holmstrup, 2003). For example, the Antarctic midge Belgica antarctica decreases the melting point of its body fluid to about $-3{ }^{\circ} \mathrm{C}$ when exposed to ice (Elnitsky et al., 2008). In theory, cryoprotective dehydration should be confined to permeable insects (Holmstrup et al. 2002). However, insects can rapidly change their cuticular permeability (e.g. Bazinet et al. 2011), dehydration is associated with cold tolerance in coleopteran larvae that might be expected to resist dehydration (e.g. Sformo paper), and has not been well-explored in temperate holometabolous insects, so it is possible that other insects that overwinter in the soil may utilize this strategy.

Acorn weevils of the genus Curculio damage mature acorns with potential impacts on the fitness of oak trees in north America and Europe (Gibson, 1982; Semel and Andersen, 1988). Female weevils lay eggs in young acorns and larvae feed and develop within the acorns. After the ripe acorns fall to the ground, fully developed larvae cease feeding and burrow into the soil to overwinter (Pélisson et al., 2012; Venner et al., 2011). Some C. glandium larvae in southeastern France might experience two winters in the soil by developing to the adult stage (Venner et al., 2011) 
but the overwintering stage for the second year in other populations, including in North America, is not clear. Although there is no apparent preference for oak species, (Crawley and Long, 1995; Espelta et al., 2009; Pélisson et al., 2012), the balance of tannin, protein and fat in acorns varies among oak species (Shimada and Saitoh, 2006). The quality of diet influences cold tolerance in insects and spiders (Koštál et al., 2012; Tanaka, 1994; Worland and Lukešová, 2000), but it is not clear whether there is a relationship between nutrition of acorns and weevil cold hardiness.

We investigated the overwintering biology of $C$. glandium overwintering in the soil in a temperate North American location: Pelee Island, southwestern Ontario, Canada. To determine the cold tolerance strategy, we measured lower thermal limits and water balance during winter and examined the contribution of dehydration and exposure to survival during a long-term mild cold temperature. We also compared the overwinter biology of $C$. glandium larvae collected from acorns of different Quercus species. This is the first study of overwintering in this species, and one of only a few that examines holometabolous insects that overwinter in the soil.

\section{Material and methods}

Insect collection and laboratory maintenance

To obtain Curculio glandium larvae, fallen acorns from bur oak, Quercus macrocarpa, and red oak, Querucus rubra, were collected in late September and early October from deciduous forests on Pelee Island, Ontario, Canada $\left(41^{\circ} 77^{\prime} \mathrm{N}, 82^{\circ} 71^{\prime} \mathrm{W}\right)$ in 2010 (both species) and 2011 (red oak only). To collect weevils, acorns (separated by oak species) were placed on a plastic screen with $2 \mathrm{~cm} \times 2 \mathrm{~cm}$ grids over c. $10 \mathrm{~cm}$ of moist soil in a plastic bin at $4{ }^{\circ} \mathrm{C}$. Larvae emerging from the acorns fell through the 
screen and burrowed into the soil, which was riddled daily to collect larvae. Larvae

114 were transferred to $120 \mathrm{ml}$ plastic jars containing $100 \mathrm{ml}$ soil (30-50 individuals per jar)

115 and stored at approximately $4{ }^{\circ} \mathrm{C}$ until use in experiments. Immediately prior to use in 116 experiments, larvae were removed from soil and blotted on a paper towel to remove soil 117 and excess water from the surface.

Supercooling point

To measure the SCP, larvae were placed in $1.7 \mathrm{ml}$ microcentrifuge tubes in contact with 36-AWG type-T copper-constantan thermocouples (Omega, Laval, Quebec, Canada). Thermocouples were connected to a Picotech TC-08 thermocouple interface and PicoLog software (Pico Technology, Cambridge, UK). The tubes containing weevils were inserted into wells in an aluminium block that was cooled by methanol circulated from a Lauda Proline 3530C refrigerated bath (Lauda, Wurzburg, Germany). The weevils were allowed $30 \mathrm{~min}$ to equilibrate at $0{ }^{\circ} \mathrm{C}$, and then cooled from $0{ }^{\circ} \mathrm{C}$ to $-30{ }^{\circ} \mathrm{C}$ at $0.1{ }^{\circ} \mathrm{C} \mathrm{min}^{-1}$. $\mathrm{SCP}$ was determined as the lowest temperature before the exotherm was observed. After measuring the SCP, the water content of each larva was measured gravimetrically as described below.

Water content

After assessing survival or measuring SCP, the larvae were weighed (wet mass) and placed in $1.5 \mathrm{ml}$ tubes. To speed drying, they were pierced ventrally with a needle. The larvae were dried at $70{ }^{\circ} \mathrm{C}$ for at least five days, and then reweighed (dry mass). The water content was calculated as the difference between fresh and dry mass of each 136 individual. 
To examine survival after a short cold exposure, weevils from red and bur oak acorns collected in 2010 were exposed to seven temperatures $(0,-3,-6,-7,-9,-12$ and $-15{ }^{\circ} \mathrm{C}$ ) and those from red oak acorns collected in 2011 were exposed to six temperatures $\left(-2,-4,-6,-8,-10\right.$ and $\left.-12{ }^{\circ} \mathrm{C}\right)$. Eight to 20 individuals were used at each test temperature. A weevil was put in a $1.7 \mathrm{ml}$ microcentrifuge tube and the tubes were cooled from $0^{\circ} \mathrm{C}$ at $0.1^{\circ} \mathrm{C} \min ^{-1}$ to the chosen temperature, held at that temperature for

$14530 \mathrm{~min}$, and then warmed to $4{ }^{\circ} \mathrm{C} \mathrm{min}$ at $0.1^{\circ} \mathrm{C} \mathrm{min}-1$. After rewarming, larvae were kept at room temperature for $15 \mathrm{~min}$ and survival was assessed in this experiment. Preliminary studies showed that survival rates estimated $15 \mathrm{~min}$ and $24 \mathrm{~h}$ after rewarming were identical. Weevils were considered alive if they crawled voluntarily. The median lower lethal temperature $\left(\mathrm{LT}_{50}\right)$, the temperature that caused $50 \%$ mortality was estimated with logistic regression in R v 3.0.3 (R Core Team, 2013).

\section{Overwintering in the field site}

For overwintering in the field, thirty larvae were placed with $100 \mathrm{ml}$ sandy loam soil in a $100 \mathrm{ml}$ plastic jar $(5.5 \mathrm{~cm}$ diameter, $6.5 \mathrm{~cm}$ depth $)$ pierced with small holes at the top and bottom. Three jars from each of red or bur oak acorns collected in 2010 and seven jars containing larvae from red oak acorns collected 2011 were placed in the field. Jars containing weevil larvae were buried at $5 \mathrm{~cm}$ depth in tilled soil in London, Ontario, Canada $\left(43^{\circ} 00^{`} \mathrm{~N}, 81^{\circ} 15^{\top} \mathrm{W}\right)$ on 18 December 2010 , and 12 November 2011. This depth was chosen because Semel and Anderson (1988) showed that most acorn weevil larvae burrowed up to $21 \mathrm{~cm}$ and about $30 \%$ of larvae was in a depth in 
less than $4 \mathrm{~cm}$. Larvae were collected through the winter every two or four weeks and SCP and water content measured.

\section{Microclimate temperatures}

Temperature data were collected at two sites: the acorn collection site (Pelee Island, $\mathrm{ON}$ ) and the tilled soil site where weevils were buried to study seasonal changes in cold tolerance (London, ON). iButton Thermochron DS1922L data loggers (Maxim Integrated Products, Sunnyvale, CA, USA) were buried approximately $5 \mathrm{~cm}$ depth at the same location as the sites collected acorns on Pelee island or included in a jar containing larvae (see above) in London. Temperatures on Pelee Island and the London site were recorded every 60 and $30 \mathrm{~min}$, respectively.

\section{The effect of cryoprotective dehydration on SCP and water content}

To assess if Curculio glandium larvae utilize cryoprotective dehydration to enhance their cold tolerance, larvae collected from red oak acorns in 2011 were placed in $1.7 \mathrm{ml} \mathrm{microcentrifuge} \mathrm{tube} \mathrm{with} \mathrm{holes} \mathrm{at} \mathrm{the} \mathrm{top.} \mathrm{A} \mathrm{group} \mathrm{of} \mathrm{five} \mathrm{tubes,} \mathrm{each}$ containing a larva, was put in a $120 \mathrm{ml}$ Parafilm-sealed jar containing approximately 80 $\mathrm{ml}$ of crushed ice. A total of eight jars containing larvae and ice were placed in an environmental test chamber (Tenney ETCU 16-RCW2.5, Thermal Product Solutions, New Columbia, PA, USA) at $0{ }^{\circ} \mathrm{C}$ for one day, and cooled at $1{ }^{\circ} \mathrm{C} /$ day to $-5{ }^{\circ} \mathrm{C}$, where they were held for seven days. To measure SCPs and water contents, four jars were removed from the chamber on the first day that temperature reached at $-5{ }^{\circ} \mathrm{C}$ and on the last day of cold exposure. Under the experimental conditions, it was expected that larvae were exposed to desiccation caused by the vapour pressure difference between 
ice and their supercooled body water (Holmstrup and Sømme, 1998; Irwin and Lee, 2002; Lundheim and Zachariassen, 1993).

\section{The effect of acclimation on cold tolerance}

To study the effect of long-term cold exposure on $C$. glandium larvae, individuals from red oak acorns collected in 2011 were kept at $0{ }^{\circ} \mathrm{C}$ for 2,4 and 6 weeks. Larvae were placed individually in $1.7 \mathrm{ml}$ microcentrifuge tubes and five tubes with larvae were contained in a $50 \mathrm{ml}$ plastic jar. To expose larvae to $0{ }^{\circ} \mathrm{C}$, jars were buried in a slurry of crushed ice and water, and placed in a Styrofoam box inside a SanyoMR-153 incubator (Sanyo Scientific, Bensenville, IL, US) set at $5{ }^{\circ} \mathrm{C}$. Ice was changed or added at least once a week and an iButton data logger was placed in the box to confirm the temperature. The SCPs and water contents of 8-21 larvae per time point were measured as described above.

Statistical analysis

Supercooling points were natural-log-transformed prior to further analysis. The SCPs, body mass and dry mass of larvae kept at $4{ }^{\circ} \mathrm{C}$ were compared among three groups, which larvae from bur and red oaks collected in 2010 and larvae from red oak collected in 2011, using one-way ANOVA followed by Tukey's post hoc test (SigmaPlot v10; Systat Software, Inc., Chicago, IL, USA). Differences in water content were investigated using analysis of covariance (ANCOVA) of water mass with wet mass as a covariate followed by Tukey's post hoc test in SPSS (v. 20; IBM, NY, UAS). 
using one-way ANOVA followed by Tukey's post hoc test (SigmaPlot) and to compare water content among sampling times ANCOVA followed by Tukey's post hoc test (SPSS) was performed. Pearson's product-moment correlation was calculated between SCP and water content in field-acclimated larvae (across all years) in SigmaPlot. One-way ANOVA followed by Tukey's post hoc test (SigmaPlot) was used to compare SCPs, body mass and dry mass among control and treated groups in the cryoprotective dehydration and acclimation experiments and ANCOVA followed by Tukey's post hoc test (SPSS) was used for comparison of water contents.

Results

Cold tolerance strategy and acute cold tolerance

$\mathrm{LT}_{50}$. The $\mathrm{LT}_{50}$ of larvae collected in 2010 was $-6.1^{\circ} \mathrm{C}$ and $-7.2^{\circ} \mathrm{C}$ for larvae from red oak and bur oak acorns, respectively. The $\mathrm{LT}_{50}$ of larvae collected in 2011 from red oak was $-6.5^{\circ} \mathrm{C}$. No larvae survived internal ice formation regardless of oak tree species or sampling year and all unfrozen larvae survived cold exposure $(\mathrm{N}=16)$.

The SCPs of larvae from bur oak acorns were significantly lower than SCPs of larvae from red oak acorns in 2010 (Fig. $1 \mathrm{~A}, F_{2}, 140=6.810, P<0.001$ ). Larvae collected from red oak acorns in 2011 had lower SCPs than larvae collected in $2010(P$ $<0.001)$. Larvae collected from bur oak acorns had significantly higher water contents than those collected from red oak acorns in 2010 (Fig. 1B, $F_{2,139}=11.183, P<0.001$ ). The water contents of larvae from red oak acorns in 2010 were significantly lower than those of larvae collected in $2011(P<0.001)$. There was no significant difference in wet (Fig. $\left.1 \mathrm{C}, F_{2,140}=1.62, P=0.201\right)$ or dry $\left(F_{2,140}=0.80, P=0.452\right)$ mass among 
larvae collected in different years or from different species of acorns.

Microclimate temperatures

Microclimate temperatures did not drop below $-2{ }^{\circ} \mathrm{C}$ during the winters of 2010-2011 or 2011-2012 at the sites where weevil larvae were buried and acorns containing larvae collected (Fig. 2). At both sites, temperatures remained between 0 and $+2{ }^{\circ} \mathrm{C}$ from late December 2010 to early March 2011. The Pelee Island site in 2011-2012 was slightly warmer; the temperature remained above $1{ }^{\circ} \mathrm{C}$ all winter (Figs 2B, 2D).

Seasonal changes in cold tolerance and water content

Seasonal changes in cold tolerance and water content of weevils buried in the field varied among species of oak and years (Fig. 3). Larvae from bur oak acorns collected in 2010 had significantly lower SCPs in January and February than in March (Fig. 3A, $F_{2,39}=12.69, P<0.001$ ). In larvae from red oak acorns collected in 2010 , the mean SCP in January was significantly lower than that in March $\left(F_{2,34}=13.82, P<\right.$ 0.001), but the SCP increased to $-7^{\circ} \mathrm{C}$ in February. However, there was no significant difference in SCPs of larvae from red oak acorn among sampling periods in $2011\left(F_{6,76}\right.$ $=1.831, P=0.104)$. In larvae collected in 2010, water content showed a pattern similar to SCP (Fig. 3B). In larvae from bur oak acorn, water content was about $0.45 \mathrm{mg} \mathrm{H}_{2} \mathrm{O} / \mathrm{mg}$ dry mass in January and February and significantly increased in March $\left(F_{2,36}=25.37, P<0.001\right)$. January water content of larvae from red oak acorns collected in 2010 was significantly lower than that of larvae in February and March $\left(F_{2,33}=14.82, P<0.001\right)$. Weevil 
larvae collected in 2011 did not show a decrease in water content; in fact water content gradually increased through the experimental period (Fig 3B). There was a significant positive correlation between SCPs and water content in weevil larvae buried in the field (Fig. $\left.4, r_{\mathrm{s}}=0.68, P<0.001\right)$.

\section{Cryoprotective dehydration}

To determine whether acorn weevil larvae utilize cryoprotective dehydration to increase cold hardiness, larvae from red oak acorns in 2011 were exposed to $-5{ }^{\circ} \mathrm{C}$ at high vapour pressure deficit for seven days. The SCPs were significantly decreased by the exposure to low temperature and high vapor presser conditions (Fig. 5B, $F_{2,81}=$ 4.171, $P=0.019$ ) and larvae after seven days exposure to $-5^{\circ} \mathrm{C}$ had significantly lower SCPs than those maintained at $4{ }^{\circ} \mathrm{C}$. Water contents were significantly different among control and treated groups (Fig 5C, $F_{2,80}=9.816, P<0.001$ ). The water contents on the first day the temperature reached $-5^{\circ} \mathrm{C}$ were significantly lower than those of control larvae, but the water contents of larvae after seven days exposure to $-5{ }^{\circ} \mathrm{C}$ did not differ significantly from those of control larvae. Neither fresh nor dry body mass differed among control and groups exposed to low temperature (wet mass: $F_{2,81}=0.670, P=$ 0.52 ; dry mass: $F_{2,81}=2.76, P=0.07$; Fig. $\left.5 \mathrm{D}\right)$.

\section{The effect of long-term acclimation on cold hardiness}

Weevil larvae obtained from red oak acorns collected in 2011 were acclimated at $0{ }^{\circ} \mathrm{C}$ for 6 weeks. Exposure to $0{ }^{\circ} \mathrm{C}$ for two and four weeks decreased the mean SCP from $-8.6 \pm 0.37^{\circ} \mathrm{C}$ (mean \pm S.E.) to $-11.3 \pm 0.87{ }^{\circ} \mathrm{C}$ and to $-11.5 \pm 0.78$ (Fig. 6A; $F_{3,106}=4.957, P=0.003$ ) but after additional cold exposure the SCP of [who?] did not 
differ significantly from control larvae. Water content of larvae kept at $0{ }^{\circ} \mathrm{C}$ for six weeks was significantly compared to control and larvae kept at $0{ }^{\circ} \mathrm{C}$ for two and four weeks (Fig. 6B, $F_{3,88}=9.285, p<0.001$ ). Neither wet nor dry body mass differed significantly among groups (Fig. $6 \mathrm{C}$, wet mass, $F_{3,105}=2.267, p=0.085$; dry mass, $\left.F_{3,105}=0.932, p=0.428\right)$.

\section{Discussion}

Curculio glandium larvae survived subzero temperature exposure for several days and were killed by internal ice formation irrespective of oak species and sampling years, suggesting that acorn weevil larvae are freeze-avoidant. Both freeze-tolerant and -avoidant species have been reported in Curculionidae species overwintering as adults (Coulson and Bale, 1996; Kandori et al., 2006; Koštál and Šimek, 1996; van der Merwe et al., 1997). However, all species studied thus far that overwinter as larvae are freeze avoidant, including C. glandium in this study (Coyle et al., 2011; Watanabe and Tanaka, 1997). The larvae of Phullobius oblongus, Polydrusus sericeus, Barypeithes pellucidus are also freeze avoidant, and their SCPs are between -9 and $-13{ }^{\circ} \mathrm{C}$ in winter (Coyle et al., 2011). Thus the SCPs of $C$. glandium larvae are not especially low compared to other freeze avoidant weevil larvae. Microclimate data showed that weevil larvae are not likely to be exposed to low sub-zero temperatures, because they are protected from freezing in their buffered overwintering site. Larvae may be even better-protected from low temperatures than our data show, because our data loggers were, at $5 \mathrm{~cm}$ depth, probably near the upper limit of the range of overwintering depths (Semel and Andersen, 1988). Thus, larvae may temperature and weevil larvae that stayed closed to the bottom of containers were likely exposed to slightly higher 
temperatures than larvae that stayed at the top of the jar.

Most freeze-avoidant insects decrease their SCP to survive low winter temperatures in winter (Denlinger and Lee, 2010). Clear seasonal changes of SCPs were observed during the winter of 2010-2011, although snow cover kept the $5 \mathrm{~cm}$ depth soil temperature at about $0.5^{\circ} \mathrm{C}$. The SCP also decreased in larvae acclimated at $0^{\circ} \mathrm{C}$ for four weeks, although the SCP did not appear to decrease in individuals kept at 0 ${ }^{\circ} \mathrm{C}$ for six weeks. Additionally, seven days' exposure to $-5{ }^{\circ} \mathrm{C}$ induced lower SCPs than $4{ }^{\circ} \mathrm{C}$ when larvae were cooled to $-5^{\circ} \mathrm{C}$ gradually. In many insect species, survival rates are increased by acclimation to low temperatures (ref), and it appears that the cold tolerance of acorn weevil larvae is enhanced by exposure to both prolonged mild and short severe temperatures. However, SCPs of weevil larvae from red oak did not decline during the winter in $2011-2012$ and the temperatures in overwintering site fluctuated more in 2011-2012 than in 2010 - 2011. These variations of cold tolerance in larvae in the soil may result from the different microclimate conditions to which larvae were exposed during winter, perhaps driven by variation in both air temperature and snow cover. This variation in acclimation means that winters with reduced snow cover (or extreme low temperatures) that lead to enhanced frost penetration could kill weevil larvae if prior conditions have not been favourable for acclimation. Moreover, the thermal conditions during development in the acorns and the moisture environment of the soil probably vary among years, and could cause interannual differences in cold tolerance.

Weevil larvae from red and bur oak acorns collected in 2010 decreased their cold tolerance in February and March, respectively. An internal factor like the termination of diapause may be the cause of the decline of cold tolerance, because in 
2010-2011, winter temperatures at $5 \mathrm{~cm}$ depth in soil remained at about $0.5{ }^{\circ} \mathrm{C}$ until March. Although there is no information about diapause in C. glandium, diapause is intimately associated with cold tolerance in many species (Lee and Denlinger, 1991). The SCPs of the beetle Aulacophora nigripennis increase in February and termination of diapause might be related to reduction of cold tolerance (Watanabe and Tanaka, 1998). Therefore, understanding the dynamics of diapause in $C$. glandium and clarifying the relationship between diapause and cold tolerance would be a useful next step in understanding the plasticity of overwintering in this species. content (Fig. 4), and we therefore investigated whether larvae utilize cryoprotective dehydration (Elnitsky et al., 2008; Holmstrup et al., 2002; Holmstrup and Sømme, 1998). Although exposure to low temperatures in the presence of ice increased cold tolerance, a change of water content did not appear to effect this change directly. Therefore, we conclude that $C$. glandium larvae do not utilize cryoprotective dehydration to increase their cold tolerance. As shown in microclimate data, the site where weevil larvae overwinter was not frozen, which means that the opportunity for cryoprotective dehydration may not exist in the field. Furthermore, C. glandium appears to be relatively dehydration-resistant (H. Udaka, unpublished observations), which would further impede the development of a cryoprotective dehydration strategy, which relies on a very permeable cuticle (Holmstrup et al., 2002). Nevertheless, there are striking changes in water content among years, which may result from among-year differences in soil moisture, which we did not measure. While these differences are reflected in cold tolerance (Figure 4), they do not appear to be modified by the animal specifically as part of the overwintering programme. 
The species of oak tree on which the weevils fed affects their cold tolerance; weevil larvae from bur oak acorns had lower SCPs than those fed on red oak acorns in 2010. Although red oak acorns have tannin levels three times higher than bur oak acorns (Dixon et al., 1997), and tannin has negative effects on growth rate in some insects (Bernays, 1981; Manuwoto and Scriber, 1986), there was no significant difference in body mass between larvae fed on bur oak and red oak acorns. Thus, the difference in nutrition may affect the ratio of body components or potential investment into cryoprotectants, rather than growth rate or body size per se. In the absence of other tradeoffs, we would expect that this indirect impact of diet on overwintering biology could lead to selection for oviposition on bur oak acorns, although at present it is not clear that weevils preferentially choose one species over another. Because the acorns came from a number of individual trees, and the larvae were assigned randomly to measures and treatments, we are unable to determine whether differences among individual trees within a species also affect cold tolerance. However, the trees have very similar locations and growth forms on Pelee Island, so we do not expect any systematic effects of tree health or location to override the coarse-scale differences in nutritive environment.

\section{Acknowledgments}

We are grateful to Dr. Mhairi McFarlane, Jill Crosthwaite and the Nature Conservancy of Canada for their support to collect acorns and acorn weevils. We also thank Kevin Olegario and Ashley Sullivan for technical assistance and Annegre Nicolai for useful advices for data analysis. This research was supported by grants from NSERC (Discovery) and the Canadian Foundation for Innovation, and an Ontario Early 
377 Researcher Award for BJS and a CBIR Government of Canada Postdoctoral Research 378 Fellowship for HU.

379 
Bernays, E., 1981. Plant tannins and insect herbivores: an appraisal. Ecol. Entomol. 6, 353-360.

Chown, L.S., Nicolson, W.S., 2004. Insect physiological ecology : mechanisms and patterns. Oxford ; New York : Oxford University Press.

$$
\text { patterns. Oxford, New York : Oxford University Press. }
$$

Coulson, S.J., Bale, J.S., 1996. Supercooling and survival of the beech leaf mining weevil Rhynchaenus fagi L. (Coleoptera: Curculionidae). J. Insect Physiol. 42, 617-623.

Coyle, D.R., Duman, J.G., Raffa, K.F., 2011. Temporal and species variation in cold hardiness among invasive rhizophagous weevils (Coleoptera: Curculionidae) in a northern hardwood forest. Ann. Entomol. Soc. Am. 104, 59-67.

Crawley, M.J., Long, C.R., 1995. Alternate bearing, predator satiation and seedling recruitment in Quercus robur L. J. Ecol. 83, 683-696.

Crosthwaite, J.C., Sobek, S., Lyons, D.B., Bernards, M.A., Sinclair, B.J., 2011. The overwintering physiology of the emerald ash borer, Agrilus planipennis fairmaire (coleoptera: buprestidae). J. Insect Physiol. 57, 166-173.

Danks, H.V., 1991. Winter habitats and ecological adaptations for winter survival, in: Lee, R.E., Denlinger, D.L. (Eds.), Insects at low temperature. Springer, pp. 231-259.

Denlinger, D.L., Lee, R.E., 2010. Low temperature biology of insects. Cambridge University Press, Cambridge.

Dixon, M.D., Johnson, W.C., Adkisson, C.S., 1997. Effects of caching on acorn tannin levels and blue jay dietary performance. The Condor 99, 756-764. 
Elnitsky, M.A., Hayward, S.A., Rinehart, J.P., Denlinger, D.L., Lee Jr, R.E., 2008. Cryoprotective dehydration and the resistance to inoculative freezing in the Antarctic midge, Belgica antarctica. J. Exp. Biol. 211, 524-530.

Espelta, J.M., Bonal, R., Sánchez-Humanes, B., 2009. Pre-dispersal acorn predation in mixed oak forests: interspecific differences are driven by the interplay among seed phenology, seed size and predator size. J. Ecol. 97, 1416-1423.

Gibson, L.P., 1982. Insects that damage northern red oak acorns. US Department of Agriculture, Forest Service, Northeastern Forest Experiment Station.

Groffman, P.M., Driscoll, C.T., Fahey, T.J., Hardy, J.P., Fitzhugh, R.D., Tierney, G.L., 2001. Colder soils in a warmer world: a snow manipulation study in a northern hardwood forest ecosystem. Biogeochemistry 56, 135-150.

Henry, H.A., 2008. Climate change and soil freezing dynamics: historical trends and projected changes. Climatic Change 87, 421-434.

Holmstrup, M., Bayley, M., Ramløv, H., 2002. Supercool or dehydrate? An experimental analysis of overwintering strategies in small permeable arctic invertebrates. Proc. Natl. Acad. Sci. U. S. A. 99, 5716-5720.

Holmstrup, M., Sømme, L., 1998. Dehydration and cold hardiness in the Arctic Collembolan Onychiurus arcticus Tullberg 1876. J. Comp. Physiol. B 168, 197-203.

Irwin, J.T., Lee, R.E., Jr., 2002. Energy and water conservation in frozen vs. supercooled larvae of the goldenrod gall fly, Eurosta solidaginis (Fitch) (Diptera: Tephritidae). J. Exp. Zool. 292, 345-350.

Kandori, I., Kimura, T., Tsumuki, H., Sugimoto, T., 2006. Cold tolerance of the sweet potato weevil, Cylas formicarius (Fabricius) (Coleoptera: Brentidae), from 
the Southwestern Islands of Japan. Jpn. J. Appl. Entomol. Zool. 41, 217-226.

Koštál, V., Šimek, P., 1996. Biochemistry and physiology of aestiv-ohibernation in the adult apple blossom weevil, Anthonomus pomorum (Coleoptera: Curculionidae). J. Insect Physiol. 42, 727-733.

Koštál, V., Šimek, P., Zahradníčková, H., Cimlová, J., Štětina, T., 2012. Conversion of the chill susceptible fruit fly larva (Drosophila melanogaster) to a freeze tolerant organism. Proc. Natl. Acad. Sci. U. S. A. 109, 3270-3274.

Kreyling, J., Henry, H.A., 2011. Vanishing winters in Germany: soil frost dynamics and snow cover trends, and ecological implications. Clim. Res. 46, 269.

Lee, R.E., Denlinger, D.L., 1991. Insects at low temperatures. Chapman \& Hall. Lundheim, R., Zachariassen, K.E., 1993. Water balance of over-wintering beetles in relation to strategies for cold tolerance. Journal of Comparative Physiology B $163,1-4$.

Manuwoto, S., Scriber, J.M., 1986. Effects of hydrolyzable and condensed tannin on growth and development of two species of polyphagous lepidoptera: Spodoptera eridania and Callosamia promethea. Oecologia 69, 225-230.

Marshall, K., Sinclair, B., 2012. Threshold temperatures mediate the impact of reduced snow cover on overwintering freeze-tolerant caterpillars. Naturwissenschaften 99, 33-41.

Pélisson, P.-F., Bel-Venner, M.-C., Rey, B., Burgevin, L., Martineau, F., Fourel, F., Lecuyer, C., Menu, F., Venner, S., 2012. Contrasted breeding strategies in four sympatric sibling insect species: when a proovigenic and capital breeder copes with a stochastic environment. Funct. Ecol. 26, 198-206. Pedersen, P.G., Holmstrup, M., 2003. Freeze or dehydrate: only two options for the 
survival of subzero temperatures in the arctic enchytraeid Fridericia ratzeli. J. Comp. Physiol., B 173, 601-609.

R Core Team, 2013. R: A Language and environment for statistical computing. $\mathrm{R}$ Foundation for Statistical Computing, Vienna, Austria.

Roland, J., Matter, S.F., 2013. Variability in winter climate and winter extremes reduces population growth of an alpine butterfly. Ecology 94, 190-199.

Semel, B., Andersen, D.C., 1988. Vulnerability of acorn weevils (Coleoptera: Curculionidae) and attractiveness of weevils and infested Quercus alba acorns to Peromyscus leucopus and Blarina brevicauda. Am. Midl. Nat. 119, 385-393.

Shimada, T., Saitoh, T., 2006. Re-evaluation of the relationship between rodent populations and acorn masting: a review from the aspect of nutrients and defensive chemicals in acorns. Popul. Ecol. 48, 341-352.

Sinclair, B.J., Renault, D., 2010. Intracellular ice formation in insects: unresolved after 50 years? Comp. Biochem. Physiol. A Mol. Integr. Physiol. 155, 14-18.

Tanaka, K., 1994. The effect of feeding and gut contents on supercooling in the house spider, Achaearanea tepidariorum. Cryo-letters 15, 361-366.

van der Merwe, M., Chown, S.L., Smith, V.R., 1997. Thermal tolerance limits in six weevil species (Coleoptera, Curculionidae) from sub-Antarctic Marion Island. Polar Biol. 18, 331-336.

Venner, S., Pelisson, P.F., Bel-Venner, M.C., Debias, F., Rajon, E., Menu, F., 2011. Coexistence of insect species competing for a pulsed resource: toward a unified theory of biodiversity in fluctuating environments. PLo

S One 6, e18039. 
477 Watanabe, M., Tanaka, K., 1997. Overwintering status and cold hardiness of Hypera

478

479

480

481

482

483

484

485

486

487

488

489 punctata. Cryobiology 35, 270-276.

Watanabe, M., Tanaka, K., 1998. Adult diapause and cold hardiness in Aulacophora nigripennis(Coleoptera: Chrysomelidae). J. Insect Physiol. 44, 1103-1110.

Williams, C.M., Marshall, K.E., MacMillan, H.A., Dzurisin, J.D.K., Hellmann, J.J., Sinclair, B.J., 2012. Thermal variability increases the impact of autumnal warming and drives metabolic depression in an overwintering butterfly. PLoS One 7, e34470.

Worland, M.R., Lukešová, A., 2000. The effect of feeding on specific soil algae on the cold-hardiness of two Antarctic micro-arthropods (Alaskozetes antarcticus and Cryptopygus antarcticus). Polar Biol. 23, 766-774. 


\section{Figure legends}

491

492

493

494

495

496

497

498

499

500

501

502

503

504

505

506

507

508

509

510

511

512

513

Fig.1. SCPs (A), water content (B), and body mass (C) of Curculio glandium larvae from bur oak acorns collected in 2010 and red oak acorns collected in 2010 and 2011. Weevil larvae were stored at $4{ }^{\circ} \mathrm{C}$ for a minimum of two weeks after collection, without any cold exposure. Different letter indicate the data were significantly different (Tukey's post hoc test, $P<0.05)$. Values are mean $\pm \mathrm{SE}$. N=25- 72 .

Fig.2. The soil temperature at $5 \mathrm{~cm}$ depth in the site where weevil larvae buried in London, Ontario in 2010 - 2011 (A) and 2011 - 2012 (B) and the acorns with weevil larvae collected on Pelee island in 2010 - 2011 (C) and 2011 - 2012 (D). Dashed lines indicate $0{ }^{\circ} \mathrm{C}$.

Fig. 3. Seasonal changes in SCP (A) and water content (B) of Curculio glandium larvae from January to March 2011 (open symbols) and from October 2011 to March 2012 (filled symbols). Weevil larvae were obtained from red oak acorns (circles) and bur oak acorns (triangles). Weevils collected from Pelee Island in fall 2010 were buried in the field on 18 December 2010 and those collected in 2011 fall were buried on 12 November 2011. The same letters indicate SCP and water content were not significantly different (Tukey's post hoc test, $P<0.05$ ). Mean \pm S.E. $\mathrm{N}=8-21$.

Fig.4. The relationship between SCPs and water content in Curculio glandium larvae buried in the fields in 2010 - 2011 and 2011 - 2012. Weevil larvae were obtained from bur oak acorns collected in 2010 and red oak acorns collected in 2010 and 2011. Weevils collected from Pelee Island in fall 2010 were buried in the field on 18 
514 December 2010 and those collected in 2011 fall were buried on 12 November 2011.

515 The data are derived from Figs $1 \mathrm{~A}$ and 1B. $\mathrm{N}=162$.

516

517 Fig.5. The experimental design (A) and the effect of cryoprotective dehydration on 518 SCPs (B), water content (C), body mass (D) in Curculio glandium larvae obtained from 519 red oak acorns in 2011. Larvae were kept at $0{ }^{\circ} \mathrm{C}$ for 1 day and temperature was 520 decreased $1{ }^{\circ} \mathrm{C} /$ day and held at $-5{ }^{\circ} \mathrm{C}$ for seven days. Supercooling points (SCPs) were 521 measured on (i) the first day temperature reached at $-5{ }^{\circ} \mathrm{C}$ and (ii) seven days after exposure to $-5{ }^{\circ} \mathrm{C}$. The same letters indicate SCP and water content data were not significantly different (Tukey’s post hoc test, $P<0.05$ ). N=18- 46 .

524

525 Fig.6. The effects of long-term acclimation on SCPs (A), water content (B) and body 526 mass (C) in larvae of Curculio glandium. Larvae collected from red oak acorns in 2011 527 were used and SCPs were measure in weevil larvae exposed to $0{ }^{\circ} \mathrm{C}$ for 2,4 , and 6 528 weeks. The same letters indicate SCPs were not significantly different (Tukey's post hoc 529 test, $P<0.05) . \mathrm{N}=12-46$. 


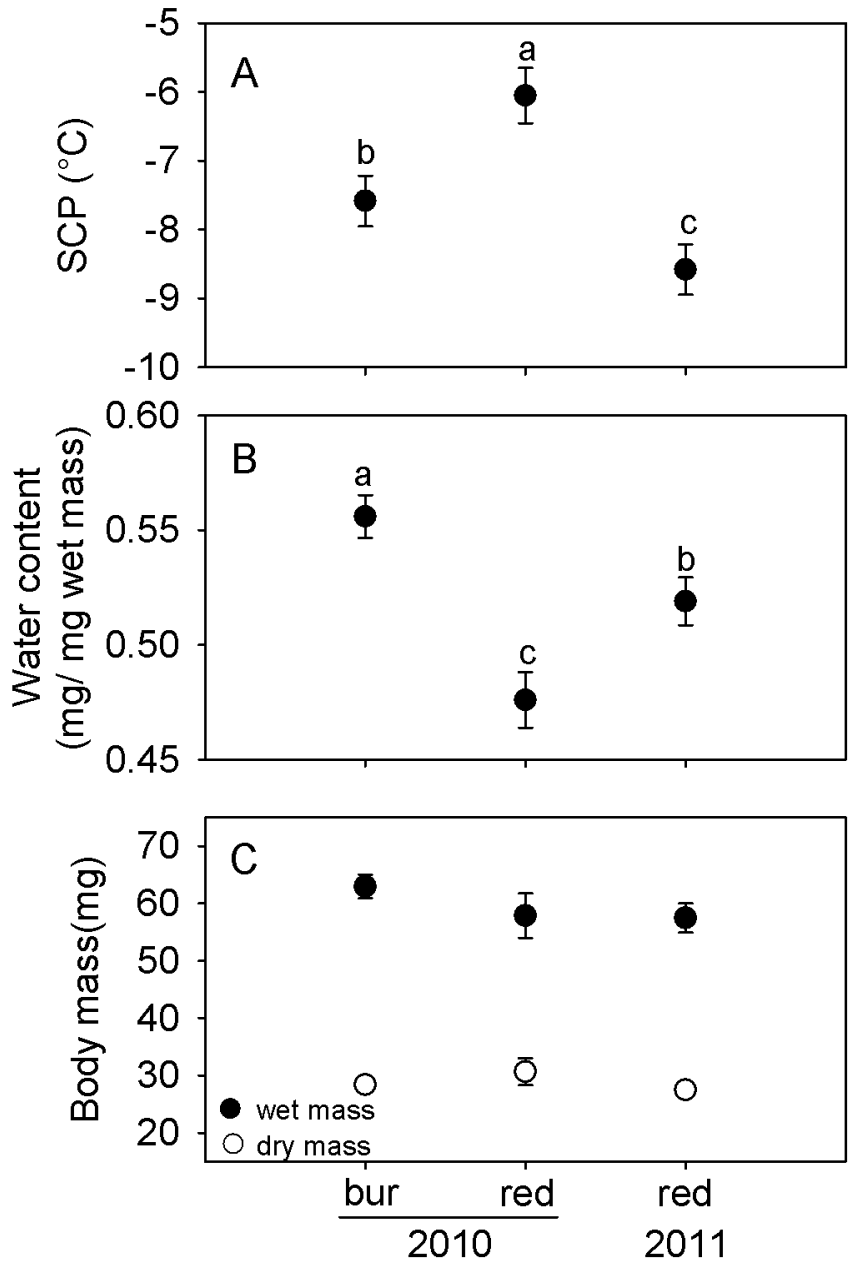



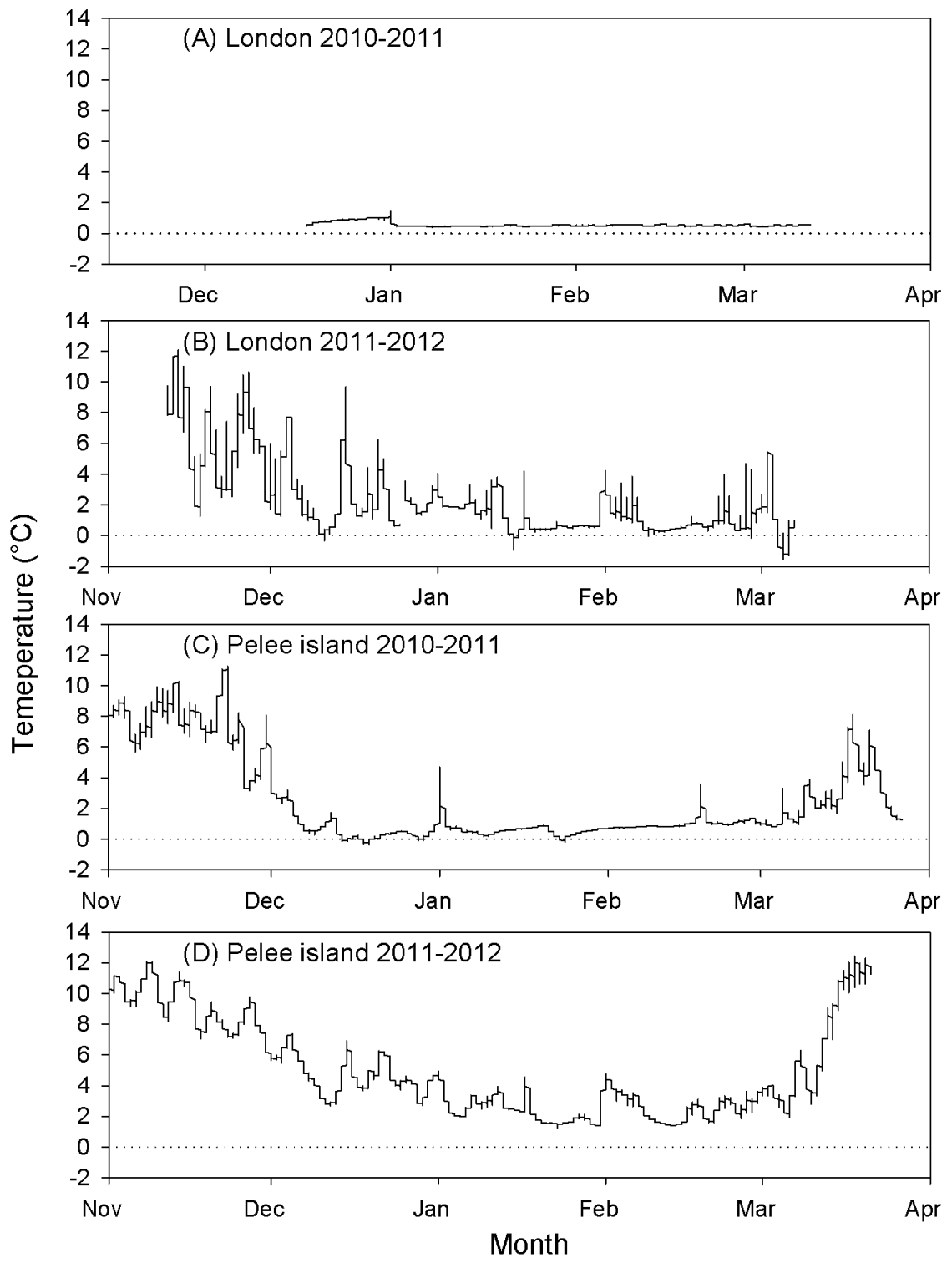
Fig3
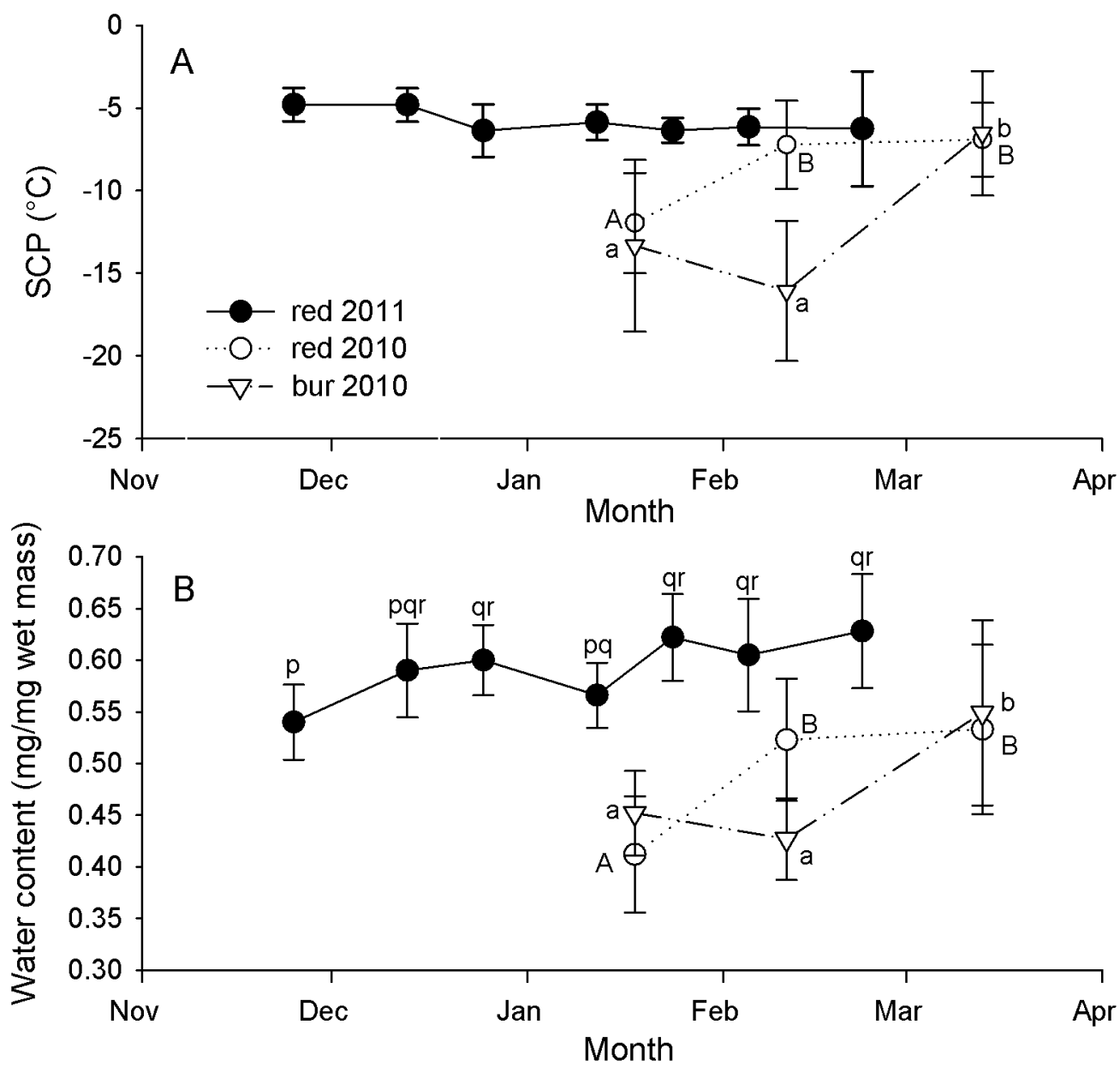
Fig 4

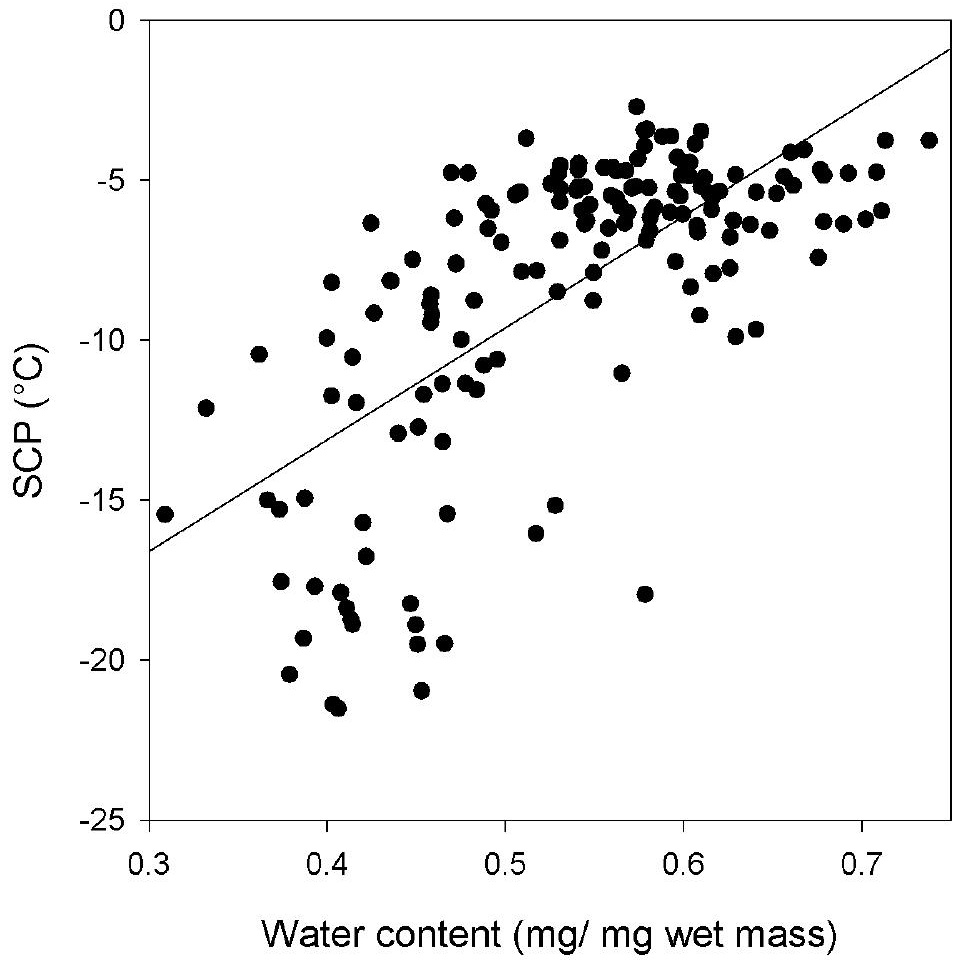


Fig 5
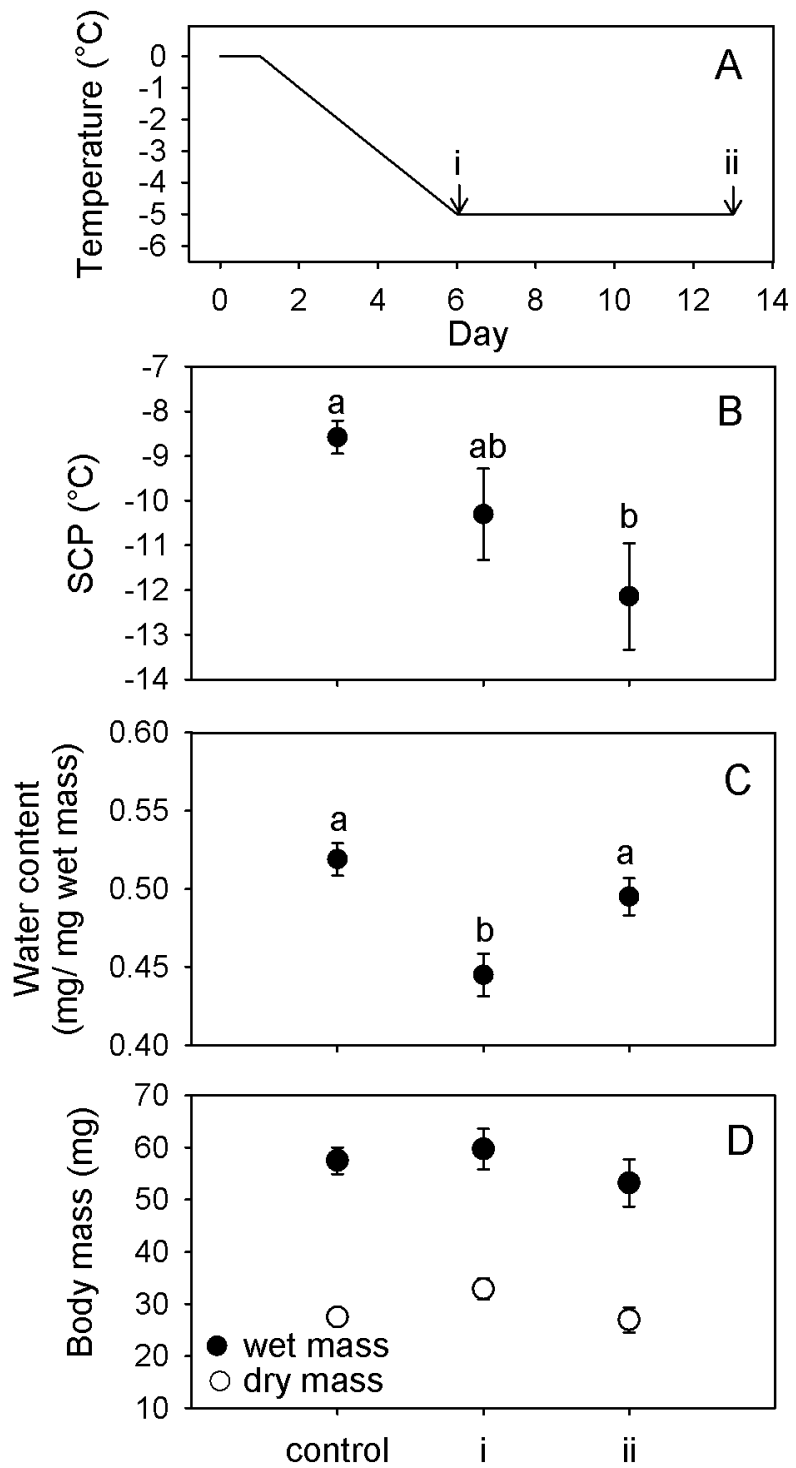

Treatment 
Fig 6

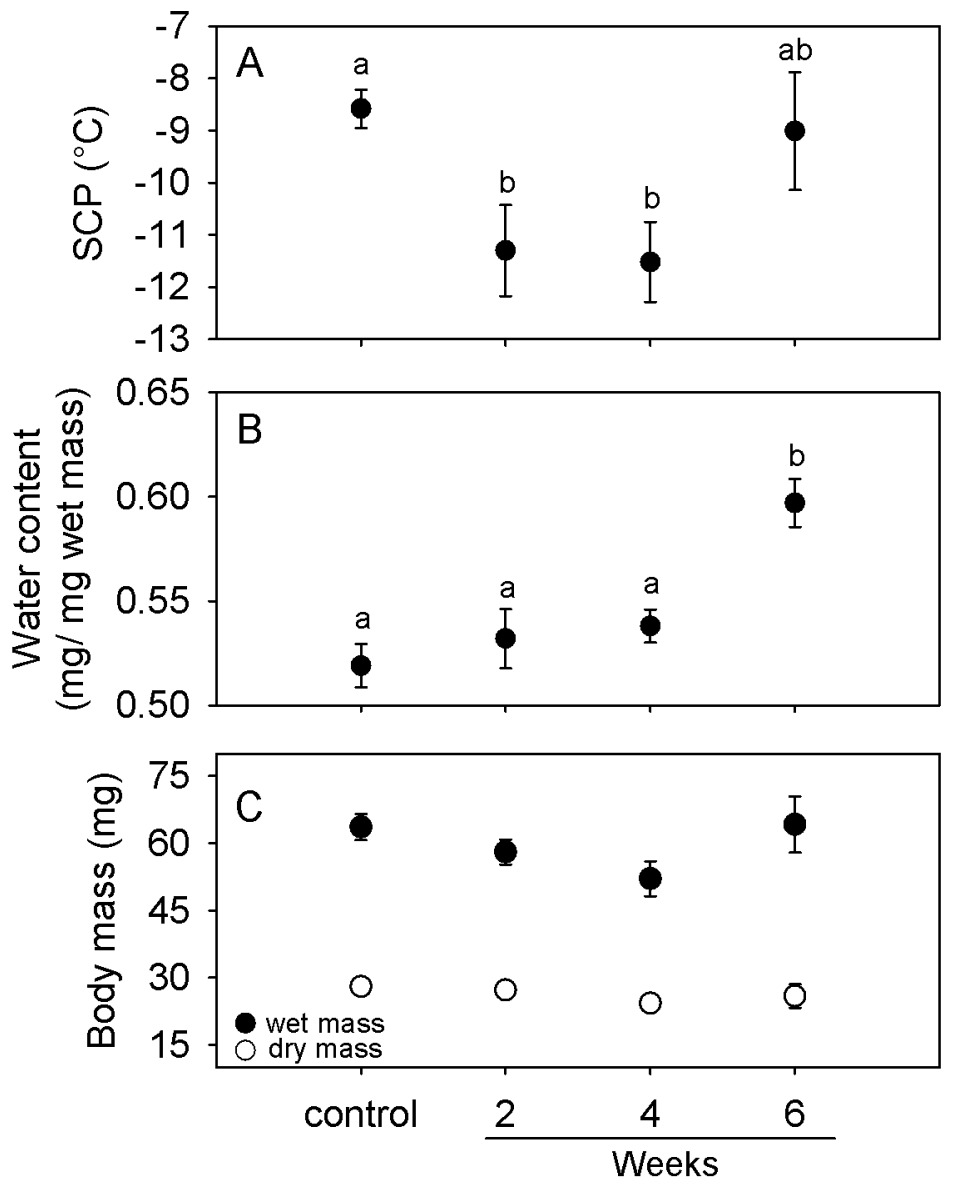

